\title{
Relations Between Characteristics of Workplace Practices and Types of Informal Work-Related Learning: A Survey Study Among Dutch Police
}

\author{
Anja J. Doornbos, Robert-Jan Simons, Eddie Denessen
}

Some organizations seek to promote informal work-related learning to stimulate organizational performance. This study focuses on six types of work-related learning in relation to personal, relational, and work characteristics of the workplace practice. A survey was conducted to identify types and levels of work-related learning for executive Dutch police officers in terms of intentionality, developmental relatedness, and interaction partner's professional practice and hierarchical position. Analysis of the data found that police officers frequently learn from their peers and together. They learn from new and less-experienced colleagues infrequently. Of the nine characteristics of workplace practices researched in this study, some seemed to individually facilitate work-related learning; in particular, the individual's value of work-related learning, possibilities for collegial feedback, and relatively high level of work pressure seemed to stimulate informal work-related learning. Implications of the findings for HRD research and practice are discussed.

Work-related learning plays a major role in initial and ongoing competence development. It implies human change or growth that occurs primarily in activities and contexts of work (Fenwick, 2001). It is integrated in work activities, tacit, predominantly unstructured, experiential, and social (Eraut, 2000; Marsick \& Watkins, 1990, 2003). The debate about work-related learning has grown as organizational leaders increase their focus on learning in organizations as a way of improving organizational performance (Rainbird, Fuller, \& Munro, 2004). Organizational leaders recognize that to compete effectively they must take action in the workplace practice that helps them learn from their experience, influence the learning of others, and create a learning environment.

The field of human resource development has a relatively rich history of examining formal work-related learning programs, such as mentoring, learning projects, and coaching (Ellström, 2001; McLean, 2005). However, our understanding of informal work-related learning is far less. We know little about how workplace practices meet the characteristics of a powerful learning environment. In other words, the interplay between 
work-related learning and the context in which it occurs has been a largely unexamined area of inquiry (Ellinger, 2005).

Because there is a great deal of focus on the need to promote informal workrelated learning in the contemporary workplace for organizational performance, this study focuses on specific types of work-related learning in relation to characteristics of workplace practice. The idea is that if we better understand work-related learning and the kind of characteristics that influence the types of informal work-related learning, new ways to facilitate and nurture work-related learning will be found that can contribute to individual and organizational performance.

This study seeks to advance our knowledge about the effects of characteristics of workplace practice on deliberate and spontaneous kinds of work-related learning. Prior research has found workplace characteristics to relate to critical reflective work behavior (Van Woerkom, 2003). The current study extends that research by examining effects of workplace characteristics on a broader range of types of work-related learning. Therefore we conducted a large-scale study to empirically test these effects. Previous studies have mainly used small-scale qualitative designs to investigate the connections between characteristics of the workplace practice and learning at work (Billett, 2002; Fuller \& Unwin, 2004a; Ellinger, 2005). Little large-scale research exists to confirm these assertions.

\section{Informal Work-Related Learning}

Work-related learning does not take place within or follow from a formally organized learning program or event but instead happens explicitly and implicitly via various workrelated and social interactions (Eraut, 2000). People can learn tacitly, detecting changes in their thinking and behavioral repertoire only at a later point. In 2004, we presented a model of spontaneous and deliberate types of work-related learning (Doornbos, Bolhuis, \& Simons, 2004). It is grounded in the theoretical foundation of Marsick and her colleagues, who developed a model of informal and incidental learning that is based on the action science model of Argyris and Schön (1996). Marsick and Watkins (1990) addressed the importance of intentional reflection for action to explicate the implicit learning. We follow Marsick and Watkins in the idea of intentionality. The notion of intentionality within the context of work-related learning was inspired by Eraut (2000) and Hodkinson and Hodkinson (2004) and refers to whether or not workers consciously engage in activities for the purpose of acquiring knowledge, skills, or new attitudes. In 
other words, the intentionality of a worker to learn may be spontaneous or deliberate (triggered by working, or planned by the worker). Spontaneous learning occurs when activities are performed with a goal other than learning in mind. This happens when the relevant activity was itself unintended or unplanned, or when an activity was planned but not with the explicit intention of learning. Changes in knowledge, skills, or attitude as a result of such activities are typically unexpected and may therefore be described as byproducts, discovery, coincidence, or (sudden) realization. Deliberate learning, in contrast, refers to those activities performed with the explicit goal of learning in mind. The resulting changes in knowledge, behavior, skills, and attitudes are planned, sought, and sometimes even premeditated. With the current study, we made an attempt to empirically test the distinction between spontaneous and deliberate types of work-related learning.

Our model also pertained to the developmental relatedness in which work-related learning activities are embedded. Work-related learning occurs through work-related interactions and contributes to both individual and socially shared learning outcomes. This means that in the interaction both partners may learn (Doornbos, van Eekelen, \& Koopmans, 2006). This is in contrast to a formally organized learning program, where the nature of the interactions between a designated trainer and trainees is designed for trainee learning.

The notion of developmental relatedness refers to how interaction between the learning worker and his or her interaction partner contributes to learning solely on the part of the worker or for the interaction partner(s) as well. The term developmental relatedness is adopted from Higgins and Kram (2001), who applied it to mentor relations that supplied psychological or career support. We applied it to all interactive work-related activities that involve an actual attainment, regardless of whether the interaction partner is in the role of mentor or not. Along these lines, we distinguish three aspects of developmental relatedness: (1) individual learning, (2) learning together, and (3) learning from others. In the case of individual learning, there is no direct social interaction resulting in learning. This does not deny that learning is always embedded in the social construction of meaning or that any interaction occurs at all. There is no direct interaction contributing to worker learning, for example, when a worker reflects individually on work situations to make sense of what has happened and what he or she can learn from it. In learning together, workers and their interaction partner(s) both contribute to each other's learning, and this occurs within the awareness of both 
partners. Both interaction partners benefit from the interaction (D'abate, Eddy, \& Tannenbaum, 2003). A two-way or mutual developmental relation exists. Both partners can simultaneously contribute to construction of knowledge, but it is also possible for an exchange of knowledge to occur. Learning together can happen in a group, be taskoriented, and be driven by a shared interest (De Laat \& Simons, 2002; Van der Krogt, 1998). In learning from others, the interaction itself contributes to the development of the worker, but not necessarily to the development of the other interactants. Basically, a one-way developmental relation exists.

Four types of interaction partners can be further distinguished, as shown in Table 1. As is seen there, the type of interaction partner depends on his or her association with the same professional practice and his or her hierarchical position within the primary workplace in relation to the learner (Doornbos, Bolhuis, \& Simons, 2004).

\begin{tabular}{lll}
\hline \multicolumn{1}{c}{ Developmental relatedness } & Deliberate Intentionality & Spontaneous Intentionality \\
Individual & Searching for specific information & Building up routine by doing the job \\
Together & Brainstorming with a group of & Unexpected insight from a discussion \\
& workers or exchange of ideas to solve & \\
arom others & Purposeful observing of role & Dealing with conflict situations \\
Within: high & modeling of superior & between you and your boss \\
Within: peer & Reflection on performance with help & Unintended observation of colleagues \\
& of a peer & with similar job \\
Within: low & Soliciting comments from & Questions from an intern set you
\end{tabular}

Illustrative Examples of 12 Types of Work-Related Learning Distinguished by Intentionality, Developmental Relatedness, and Interaction Partner's Professional Practice and Hierarchical Position 
If the interaction partners are not part of the same primary workplace and professional practice, the category outside applies (D'abate et al., 2003; Kram, 1985). Studies of situated learning and socialization have shown people outside the primary workplacepartners, friends, family members, clients, people in other organizations-also often play an important role in work-related learning (Eraut, Alderton, Cole, \& Senker, 1998; Palonen, Hakkarainen, Talvitie, \& Lehtinen, 2003). Learning from people outside the primary workplace happens, for example, in the case of the need for critical information for one's work through professional networks, highly depending on personal contacts and learning from suppliers and customers (Eraut et al., 1998). If the interaction partners are part of the same primary workplace, the category within applies. Interaction partners inside the primary workplace have different "relative positions in the social hierarchy" in relation to the employee (learner) and can be higher, peer or, lower (Levy, Collins, \& Nail, 1999, p. 723). We expect this variability in position gives rise to differences in developmental relatedness and learning possibilities. Interaction partners with a higher position than the learner herself are expected and often found to enhance worker learning because the person with the higher position is more knowledgeable in specific content areas (Salomon \& Perkins, 1998). Furthermore, interaction partners with a higher position contribute to learning on the basis of differences in power as well. Colleagues with a peer position can contribute to worker learning through peer consultation, reflection, discussion, and evaluation. Interaction partners with a lower position-for example, new colleagues or interns - contribute to worker learning, at times for instance in asking questions or helping and offering innovative ideas (Fuller \& Unwin, 2004b).

\section{Potential Characteristics of Workplace Practices That Influence Work-Related Learning}

Considerable exploratory and descriptive research has been conducted on those factors that appear to inhibit or stimulate work-related learning (Ellinger, 2005; Eraut et al., 1998). To select variables for this study, we reviewed the literature on workplace characteristics and selected a sample of frequently mentioned relevant characteristics that could affect the frequency of work-related learning. Because of the general character of this descriptive study on work-related learning, we have chosen to select relevant characteristics, taking a broad perspective on the workplace practice that offers organizational leaders and HRD practitioners opportunities to facilitate and nurture work- 
related learning. As a result, the selected characteristics consisted of personal, relational, and work characteristics.

Selected personal characteristics are perceived level of competence and the individual's value of work-related learning. These two personal characteristics are expected to positively relate to work-related learning because previous research points at beneficial effects of positive beliefs about personal capabilities to achieve and having a commitment to lifelong learning (Kwakman, 1999; Lohman, 2005; McCauley \& Hezlett, 2001; Van Woerkom, 2003).

Selected relational characteristics are social integration with colleagues, managerial support, possibilities for collegial feedback, and the chance to participate in a network. The frequency with which employees perform informal work-related learning activities may be influenced by the nature of the relationship between the interaction partner and the learner (Ryan \& Deci, 2000, Eddy, D’Abate, Tannenbaum, GivensSkeaton, \& Robinson, 2006). Experience of social integration with colleagues refers to feelings of belongingness and connectedness to others, and being integrated into the work community and acknowledged by colleagues (Ryan \& Deci, 2000). Previous empirical research has shown a positive association of such feelings with formal learning activities (Straka, 1999) and an indirect positive association with critical reflection on work behavior (Van Woerkom, 2003). The nature of the relationship with interaction partners in the work practice is also characterized by managerial support in terms of encouragement and provision of resources. Finally, the possibilities for collegial feedback and participation in a network are expected to positively link with work-related learning as well.

Selected work characteristics are task variation, task autonomy, and work pressure. Whether or not employees find themselves in a variety of tasks that give them novel or challenging work situations can clearly foster work-related learning (Billett, 2002; Engeström, 1999; Kwakman, 1999; McCauley, Ruderman, Ohlott, \& Morrow, 1994). Task autonomy refers to the extent to which an individual has control over the conduct of a task. In cases of high task autonomy, the employee is free to select the methods and procedure for completion of a task; in cases of low task autonomy, the worker has little or no control over how a task is to be performed (Ellström, 2001). The role of task autonomy in learning seems to be ambiguous. Ellström (2001) expects that a higher level of task autonomy fosters creative learning. In previous empirical studies, though, task autonomy has not been found to play a role in performance of professional 
activities and critical reflective work behavior (Kwakman, 1999; Van Woerkom, 2003). The role of work pressure has been found to be ambiguous as well. Work pressure refers to the extent workers feel they have to work hard and fast. On the one hand, work pressure is mentioned as a significant factor in exploratory studies of what workers experience as inhibiting work-related learning. On the other hand, survey studies reveal a positive association between work pressure and the performance of professionals and critical reflective work behavior (Van Woerkom, 2003).

In general, our study empirically examines the potential relationship between the selected personal, relational, and work characteristics and the frequency of informal work-related learning.

\section{The Case of the Dutch Police}

The present study was conducted within the specific context of the Dutch police force; it sponsored the research effort. The national Dutch police force consists of 25 regional agencies and one national independent agency. About 30,000 police officers constitute the basic police force, conduct executive work, and have at least two years' police tenure (Core Information Dutch Police 2004, 2005). Today's police officers (and future officers) perform their work in a constantly changing, multiform society. The decrease of social control, and the increase of (global) criminality, for example, have greatly affected police functioning, not only in the Netherlands but in the rest of the world as well. Balancing the power and service function makes work at the police force diverse, challenging, and unpredictable. The police force aims to be more externally oriented, to establish more extensive and better collaborative ties with other organizations. These shifting objectives and changes place high demands on the individual police officer and the professionalism of the police force in general. As a response to these developments, the Police Academy of the Netherlands and the Dutch police forces are searching for ways to stimulate work-related learning.

\section{Research questions}

To learn more about the relations between workplace characteristics of Dutch police officers and specific types of work-related learning, two research questions guided the study: 
1. Which types and levels of work-related learning can be identified for executive Dutch police officers in terms of intentionality, developmental relatedness, and interaction partner's professional practice and hierarchical position?

2. What are the levels of characteristics of the workplace practice of executive Dutch police officers, and how do they relate to the types of work-related learning identified?

\section{Method}

A one-group descriptive survey approach allowed us to explore how the variables of interest interrelated for a group of Dutch police officers.

\section{Sample}

The sample for this study was obtained via contact persons of 10 out of 25 regional police agencies. The contact persons worked in either the personnel or human resource development department and were willing to distribute the questionnaires to executive police officers who had been working at least two years at the police force. These aspects ensure that they perform comparable police tasks and that they have had enough possibilities to reflect on frequency of learning experiences. We asked the contact persons how many potential respondents they were willing or able to reach within the regional police agency. Of the approximately 1,090 police officers invited by the contact persons to take part in the present study, 473 (43\%) agreed to participate and filled out the questionnaire on paper.

The questionnaire was distributed between June and October 2003 along with a self-addressed envelope and a brochure informing potential participants about the goals of the study and content areas, directions for completion and return of the questionnaire, and where to go with any questions. Potential participants were ensured that their decision to take part in the study was completely voluntary and independent of any workrelated responsibilities or evaluations, and also that the content of their responses would remain confidential and reported only in aggregated form. All contact persons sent a reminder to encourage the police officers to take part in the study. The names of the police officers invited to participate in the study remained anonymous to the researchers. This is important to raise the response rate. 
The participating police officers represent 10 out of 25 regional agencies, which varied with respect to location (urban versus rural) and size (large versus small). Among the respondents, 105 (22\%) were female and 368 (78\%) were male. This is considered representative of the population of 10 police agencies, where $82 \%$ of the police officers are male and $18 \%$ are female (Core Information Dutch Police 2004, 2005). Of the participating police officers, 241 (51\%) did not hold a job outside the police vocation during their last three career steps, whereas 232 (49\%) held at least one job outside the police vocation. The mean age of the sample was 39 years $(s d=9.13)$. This is considered slightly different from the total group of 10 police agencies, where the mean age was 41 years (Core Information Dutch Police 2004, 2005). The mean number of years of police tenure was 15.8 ( $\mathrm{sd}=10.65)$, of which 4.62 were in the current job ( $\mathrm{sd}=$ 4.90).

\section{Instruments}

Because of the lack of available questionnaires to assess work-related learning and selected characteristics of workplace practices, we developed a questionnaire, the Learning from Police Work Questionnaire (LPWQ), partly by modifying scales from related areas and partly by developing new scales. The questionnaire contained a total of 90 items to measure 21 variables, of which 12 referred to types of work-related learning (50 items) and nine referred to characteristics of the workplace practice (40 items).

According to Table 1, in this study 12 types of work-related learning at the activity level have been conceptualized in terms of learner perceptions of work-related learning frequency. The 50 items (that is, instances of work-related learning) were generated on the basis of a previous interview study of police officers (Doornbos, Bolhuis, \& Denessen, 2004). The responses to the questionnaire items were supplied along a seven-point Likert-type rating scale ranging from never (0) to every day (6); respondents were asked to rate the frequency in which they engaged in learning activities. For example, the rating of "watching a new colleague who just graduated, I noticed that I could perform a task in a similar way" was used to indicate the respondents' level of spontaneously learning from new and less-experienced colleagues. To measure the selected characteristics of workplace practices, we used scales and items from two existing questionnaires (Van Veldhoven \& Meijman, 1994; Van Woerkom, 2003). To keep the LPWQ as compact as possible, the number of items per scale was reduced as 
far as the content of the original scales would allow. Some of the original items were slightly adjusted, and items specific to police work were added to some of the scales. The responses to the questionnaire items that referred to personal characteristics were given along a five-point Likert-type rating scale ranging from strongly disagree (1) to strongly agree (5). For example, the rating of "I think that I, as a police officer should share my ideas regarding good police work with my coworkers in order to learn from each other" was used to indicate the perceived level of value of work-related learning. The responses to the questionnaire items that referred to relational and work characteristics were given along a seven-point Likert-type rating scale ranging from never (0) to every day (6). "I decide how much time I spend on an activity" is an example of assessing the level of perceived task autonomy.

To assess the content validity of the LPWQ, seven HRD professionals undertook an initial screening. This screening led to slight adjustments in the formulation of some items of the questionnaire; for example, "reflecting on an event gave new ideas" was changed into "reflecting on an event suddenly gave new ideas" to stress the spontaneous character more. To ensure that no problems with regard to form or reading comprehension of the items would occur and that the items were reasonable and did not ask the participants overly intrusive questions, about 50 police officers were consulted in groups of 10. This consultation again led to small adjustments in the formulation of items that would make them more appropriate - for example, "chatting with external police interaction partners and they came with interesting ideas" was changed into "chatting with citizens and they came with interesting ideas."

To assess the construct validity of the questionnaire, the individual survey items were subjected to an exploratory factor analysis. Two separate factor analyses were applied. First, the ratings of work-related learning were analyzed. The second factor analysis was performed on the ratings of workplace characteristics. The appendices to this article present the measures, their composing items, and the results of the factor analyses.

Initial factor analysis of the ratings of work-related learning revealed that the distinction between both intentionality dimensions (spontaneous versus deliberate) could not be empirically validated. The number of items for further analysis could therefore be reduced considerably. For analysis of the dimensionality of developmental relatedness and interaction partner's professional practice and hierarchical position, 25 items were used. Because of relatively high intercorrelations of the factors in the analysis, oblimin 
rotated pattern coefficients were inspected to identify distinct dimensions of work-related learning activities. From the percentages of explained variance of successive factor solutions, six factors, accounting for 53 percent of the item variance, could be distinguished: (1) learning from peer colleagues (5 items, alpha $=.83$ ), referring to learning from colleagues via observation, asking questions, and searching for information; (2) learning individually (3 items, alpha $=.73$ ), referring to individual preparation or application of something new; (3) learning from outsiders (5 items, alpha $=.81$ ), referring to accumulation of suggestions from people outside the police vocation such as local residents or partners in livability and safety; (4) learning from new and less experienced colleagues ( 6 items, alpha $=.86$ ), referring to observation or discussion with new and less-experienced colleagues who have a lower position in the organizational hierarchy; (5) learning together (3 items alpha $=.76$ ), referring to mutual exchange of knowledge of which both the individual worker and his or her interaction partner(s) benefit; and (6) learning from expert colleagues ( 3 items, alpha $=.71$ ), referring to asking for help or advice with regard to a new situation. Interpretation of this final scale is slightly different from the intended scale "learning from others within: high," because the experts do not necessarily have a higher position in the organizational hierarchy. After having assessed the dimensionality and reliability of the scales, we computed six variables, taking the respondents' mean score on the items referring to each type of work-related learning.

For the construct validity of the questions about characteristics of the workplace practice, factor analysis was also applied. Nine factors that reflected the nine intended characteristics mentioned earlier, accounting for 60 percent of the item variance, could be distinguished: (1) perceived level of competence (6 items, alpha = .80), (2) value of work-related learning ( 5 items, alpha = .62), (3) social integration with colleagues ( 3 items, alpha = .73), (4) managerial support (8 items, alpha =.90), (5) possibilities for collegial feedback ( 2 items, alpha =.73), (6) possibilities to participate in a network (2 items, alpha $=.78),(7)$ task autonomy (6 items, alpha $=.81)$, (8) task variation (4 items, alpha $=.86)$, and $(9)$ work pressure $(4$ items, alpha $=.68)$. Again, variables were computed by calculating the respondents' mean score on the items referring to each characteristic of the workplace practice.

Given the nature of the study on an individual activity level, we also asked the police officers their gender and police tenure. Gender and tenure were used as control 
variables in the analyses of effects of characteristics on the level of work-related learning.

\section{Data Analysis}

Multiple regression analyses were applied to test the effects of workplace characteristics on work-related learning. For each type of work-related learning, separate analyses were performed. The standardized regression weights $\left(\beta^{\prime} \mathrm{s}\right)$ and $R^{2}$ values were supplemented by structure coefficients $\left(r_{s}\right)$ that are not suppressed or inflated by collinearity (Courville \& Thompson, 2001).

\section{Results}

To answer the first research question on types and levels of work-related learning in terms of intentionality, developmental relatedness, and interaction partner's professional practice and hierarchical position, Table 2 is presented. The table reports the means and standard deviations as well as the correlation matrix for six types of work-related learning.

\begin{tabular}{|c|c|c|c|c|c|c|c|}
\hline Type of Work-Related Learning ${ }^{1}$ & Mean & SD & 1 & 2 & 3 & 4 & 5 \\
\hline 1. From peer colleagues (peer) & 2.55 & 1.02 & & & & & \\
\hline 2. Individually (individual) & 2.32 & 1.15 & $.55^{*}$ & & & & \\
\hline 3. From outsiders (outsider) & 2.01 & 1.06 & $.57 *$ & $.61 *$ & & & \\
\hline 4. From new and less experienced-colleagues (new) & 1.86 & .93 & $.65^{*}$ & $.59 *$ & $.64^{*}$ & & \\
\hline 5. Together (together) & 2.55 & 1.10 & $.55^{*}$ & $.59 *$ & $.55^{*}$ & $.62 *$ & \\
\hline 6. From expert colleagues (expert) & 2.51 & 1.07 & $.60^{*}$ & $.50 *$ & $.46^{*}$ & $.58^{*}$ & $.55^{*}$ \\
\hline
\end{tabular}

Table 2. Descriptive Statistics and Correlations of Six Types of Work-Related Learning Note: ${ }^{*} \mathrm{p}<.05 ; 1=$ scores could range from 0 to 6 .

The mean scores of the six types of work-related learning indicate that the respondents showed a relatively low frequency of work-related learning, with mean scores ranging from 1.86 for learning from new and less-experienced colleagues to 2.55 for learning from peer colleagues and learning together. The intercorrelations among types of work- 
related learning suggest that respondents who showed one type relatively frequently were inclined to show other types frequently as well.

To answer the first part of the second research question on levels of characteristics of the workplace practice, Table 3 reports the means and standard deviations as well as the correlation matrix for nine characteristics of the workplace practice.

\begin{tabular}{|c|c|c|c|c|c|c|c|c|c|c|}
\hline Workplace Characteristics & Mean & SD & 1 & 2 & 3 & 4 & 5 & 6 & 7 & 8 \\
\hline \multicolumn{11}{|l|}{ Personal characteristics $^{1}$} \\
\hline Perceived level of competence & 4.03 & .44 & & & & & & & & \\
\hline Value of work-related learning & 4.16 & .41 & $.37 *$ & & & & & & & \\
\hline \multicolumn{11}{|l|}{ Relational characteristics ${ }^{2}$} \\
\hline Social integration with colleagues & 3.93 & .54 & $.21 *$ & $.31 *$ & & & & & & \\
\hline Managerial support & 2.11 & 1.15 & -.07 & .08 & $.20 *$ & & & & & \\
\hline Possibilities to participate in network & 3.63 & 1.77 & $.16^{*}$ & $.16^{*}$ & $.16^{*}$ & $.26^{*}$ & & & & \\
\hline Possibilities for collegial feedback & 3.14 & 1.38 & -.04 & $.11 *$ & $.29 *$ & $.42 *$ & $.22 *$ & & & \\
\hline \multicolumn{11}{|l|}{ Work characteristics ${ }^{2}$} \\
\hline Task variation & 5.28 & .96 & $.13^{*}$ & $.10 *$ & $.34 *$ & $.18^{*}$ & $.26^{*}$ & $.27 *$ & & \\
\hline Task autonomy & 4.59 & 1.09 & $.17 *$ & $.11 *$ & .04 & .09 & $.33 *$ & .02 & $.29 *$ & \\
\hline Work pressure & 3.25 & 1.21 & -.01 & $.14 *$ & .02 & .05 & .01 & .01 & -.01 & .02 \\
\hline
\end{tabular}

Table 3. Descriptive Statistics and Correlations of Nine Characteristics of the Workplace Practice

Note: ${ }^{*} p<.05 ; 1=$ scores could range from 1 to $5 ; 2=$ scores could range from 0 to 6 .

Respondents seemed to rate their level of competence quite high, and they highly valued work-related learning. Also, the respondents reported a high level of task variation and task autonomy. Relational workplace characteristics were rated at a lower level; in particular, the level of managerial support was rated low. Correlations among the nine workplace characteristics were not very high. Correlations among personal characteristics as well as among relational characteristics showed these characteristics to interrelate statistically significantly. Also, the level of task variation seemed to relate to 
the level of task autonomy. The level of work pressure, though, seemed not to relate strongly to other workplace characteristics.

To answer the second part of the second research question, on how characteristics relate to the types of work-related learning identified, we performed six regression analyses, for each type of work-related learning separately. The results of these analyses are presented in Table 4.

\begin{tabular}{|c|c|c|c|c|c|c|c|c|c|c|c|c|}
\hline & \multicolumn{12}{|c|}{ Types of Work-Related Learning } \\
\hline & \multicolumn{2}{|l|}{ Peer } & \multicolumn{2}{|c|}{ Individual } & \multicolumn{2}{|c|}{ Outside } & \multicolumn{2}{|c|}{ New } & \multicolumn{2}{|c|}{ Together } & \multicolumn{2}{|c|}{ Expert } \\
\hline & $\beta$ & $r_{s}$ & $\beta$ & $r_{s}$ & $\beta$ & $r_{s}$ & $\beta$ & $r_{s}$ & $\beta$ & $r_{s}$ & $\beta$ & $r_{s}$ \\
\hline \multicolumn{13}{|l|}{ Workplace characteristics } \\
\hline \multicolumn{13}{|l|}{ Personal characteristics } \\
\hline Perceived level of competence & -.02 & -.06 & -.03 & .06 & .04 & .18 & -.05 & -.08 & $-.07 *$ & -.09 & $-.12 *$ & -.39 \\
\hline Value of work-related learning & $.22 *$ & .48 & $.17 *$ & .54 & $.16^{*}$ & .44 & $.14 *$ & .34 & $-.14 *$ & .39 & $.12 *$ & .15 \\
\hline \multicolumn{13}{|l|}{ Relational characteristics } \\
\hline Social integration with colleagues & -.10 & .18 & -.05 & .17 & -.11 & .16 & -.08 & .11 & .06 & .41 & .00 & .22 \\
\hline Managerial support & .06 & .44 & .06 & .48 & -.01 & .37 & .06 & .55 & .06 & .55 & .10 & .49 \\
\hline Possibilities for collegial feedback & $.23^{*}$ & .66 & $.20 *$ & .69 & $.26 *$ & .59 & $.29 *$ & .80 & $.24 *$ & .74 & $.23 *$ & .71 \\
\hline Possibilities to participate in network & .05 & .21 & .06 & .34 & $.35^{*}$ & .75 & .06 & .29 & $.15^{*}$ & .42 & -.00 & .05 \\
\hline \multicolumn{13}{|l|}{ Work characteristics } \\
\hline Task variation & .03 & .24 & .01 & .25 & .00 & .28 & -.00 & .24 & -.04 & .25 & .01 & .24 \\
\hline Task autonomy & -.02 & -.07 & .05 & .23 & -.05 & .17 & -.08 & -.09 & -.02 & .05 & .01 & -.09 \\
\hline Work pressure & $.11^{*}$ & .23 & $.14^{*}$ & .50 & $.12 *$ & .25 & $.13 *$ & .38 & $.10^{*}$ & .31 & .09 & .16 \\
\hline Gender & -.02 & .01 & -.10 & -.22 & -.05 & -.28 & -.05 & -.16 & -.06 & -.13 & .05 & .27 \\
\hline Police tenure & $-.28 *$ & -.55 & $-.15^{*}$ & -.13 & -.03 & .11 & -.09 & -.26 & $-.15^{*}$ & -.20 & $-.27 *$ & -.70 \\
\hline$R^{2}$ & \multicolumn{2}{|c|}{$.21 *$} & \multicolumn{2}{|c|}{$.15^{*}$} & \multicolumn{2}{|c|}{$.27 *$} & \multicolumn{2}{|c|}{$.17 *$} & \multicolumn{2}{|c|}{$.20 *$} & \multicolumn{2}{|c|}{$.22 *$} \\
\hline
\end{tabular}

Table 4 Regression Analyses: Standardized Regression Weights (B), and Structure Coefficients $\left(r_{s}\right)$ for Predictors of Six Types of Work-Related Learning $(N=377)$ Note: ${ }^{*} p<.05$.

The results of the regression analysis show that the workplace characteristics were able to explain about $20 \%$ of the variance of frequencies of work-related learning activities.

For each type of work-related learning, the overall effects of workplace characteristics reached the set level of significance $(p<.05)$.

Overall, high scores for the value of work-related learning, possibilities for collegial feedback, and work pressure, as well as short tenure, seemed to be associated with more frequent learning activities. Specifically, the beta-coefficients for the effects of 
characteristics of the workplace practice on each type of work-related learning proved to differ slightly across types of work-related learning. For learning from outsiders as well as for learning together, participation in a network showed statistically significant positive effects. This means that participation in a network seems to stimulate learning with peers and from outsiders. Respondents' perceived level of competence seemed to negatively affect learning together and learning from experts. Apparently, a higher level of competence may inhibit these types of work-related learning. Additionally, the value of work-related learning showed a statistically significant negative standardized regression coefficient for learning together, which indicates that respondents who highly value workrelated learning are inclined to learn together with colleagues less frequently. This result is likely to be caused by the relatedness of the value of work-related learning with other workplace characteristics, because the structure coefficient shows a positive relation between value of work-related learning and learning together $\left(r_{s}=.39\right)$. Whereas the standardized regression coefficient shows the unique effect of value of work-related learning, the structure coefficient shows the relation between the value of work-related learning with the predicted scores on learning together based on all nine independent variables. The structure coefficient, which is not affected by collinearity caused by interrelations among predictors, thus suggests the value of work-related learning to positively affect learning together. In general, structure coefficients were higher than the standardized regression coefficients, which means that variation of work-related learning can only partly be ascribed to individual characteristics of the workplace practice and is better predicted by interlinked sets of workplace characteristics.

\section{Discussion}

The present study had two objectives. The first was to identify types and levels of workrelated learning for executive Dutch police officers in terms of intentionality, developmental relatedness, and interaction partner's professional practice and hierarchical position. The second objective was to gain insight into how characteristics of the workplace practice relate to the types of work-related learning identified.

Of the 12 theoretically identified types of work-related learning, only six were identified for executive Dutch police officers. The interaction partner's hierarchical position was more understood in terms of expertise and informal hierarchy than in terms of formal position. Intentionality was not reflected separately in terms of spontaneous or 
deliberate learning in the structure of the LPWQ questionnaire. We see two possible explanations for this finding.

First, police officers may be relatively unaware of their intention to learn compared to the other notions of work-related learning, namely developmental relatedness and types of interaction partners. That is, it may be easier to be aware of work-related learning activities in terms of who was involved and whether there was mutual learning or not than whether intentionality was deliberate or spontaneous. Secondly, deliberate and spontaneous learning may be found inextricable using a questionnaire as a research instrument. The question of how to identify spontaneous learning is a serious issue confronting researchers interested in work-related learning. Literature on implicit learning suggests that researchers should establish conditions that rule out the possibility of participants using intentional learning strategies so that we can see how implicit learning differs from explicit learning (Stadler \& Roediger, 1998). The LPWQ probably does not present these conditions clearly enough. In a previous interview study, however, the distinction between spontaneous and deliberate learning could be made (Doornbos et al., 2004). This indicates that interviews better permit insight into tacit processes and interpretations of experiences of the learner.

With this study, insight was gained into how characteristics of the workplace practice relate to six types of work-related learning for police officers. Two characteristics stand out because they were associated with all six types of work-related learning, namely, the personal characteristic value of work-related learning and the relational characteristic of possibilities for collegial feedback. High scores on value of work-related learning are associated with high scores on all types of work-related learning, although the relation with learning together was less unambiguous. Apparently, the frequency of work-related learning is dependent on the police officer's attitude toward work-related learning. Another interesting finding is the relation between perceived level of competence and work-related learning. High scores on this personal characteristic were negatively associated with learning together and learning from experts. Police officers may feel a need for learning when they perceive their level of competence relatively low. This felt need for learning, then, is actualized by engaging more frequently in learning collaborative learning activities and learning from experts.

Another important characteristic of workplace practices is having possibilities for collegial feedback (and the correlated relational characteristics social integration and managerial support). Possibilities for collegial feedback stimulate all identified types of 
work-related learning. Having colleagues who reflect on one's work and give constructive criticism seems invaluable for work-related learning. Given the relatively low frequency of these relational characteristics, the police organization could stimulate work-related learning by investing in managerial support and possibilities for collegial feedback.

A high level of work pressure in the police organization seemed to stimulate work-related learning. When police officers feel that they have to work hard and fast, they tend to engage more in learning activities. This finding supports the results of a study by Van Woerkom (2003) that reveals a positive relation between work pressure and the performance of professionals and critical reflective work behavior.

In contrast to the other three important characteristics of the workplace practice, it is peculiar to find that task autonomy and variation are not significantly related to any of the six identified types of work-related learning.

Also striking was the finding that police tenure is negatively associated with four types of work-related learning. More experienced police officers tend to lower their frequency of learning activities. The findings of this study indicate that more research on job and task specifications of experienced employees is needed to discover how their work may continue to invite them to learn (Thijssen, 2006).

\section{Implications for Human Resource Development}

Of the nine characteristics of workplace practices researched in this study, some seemed to individually facilitate work-related learning, especially the individual's value of work-related learning, possibilities for collegial feedback, and a relatively high level of work pressure. As we stated at the end of the results section, it may be profitable to analyze effects of workplace characteristics in a more integrated way, because the unique effects of individual characteristics were lower than the combined effects of characteristics of the workplace practice. The results of our study offer HRD professionals a basis for designing inviting learning environments for work-related learning. Learning trajectories can be considered a powerful learning environment when they integrally attend to the individual values about what kind of situation invites them to learn, and offer many possibilities for constructive criticism and feedback on how others think about the individual's performance and a sense of urgency and necessity to develop. Police officers may be stimulated to use the hidden power of their social networks more to stimulate organizational performance. Also, managers may fulfill 
different roles in stimulating their employees' learning, by facilitating collegial feedback and time and space for participation in a (learning) network.

\section{Limitations of the Study}

The questionnaire items that were applied in this study do not present conditions that trigger individuals to indicate spontaneous and deliberate learning.

Furthermore, the relations between the characteristics of workplace practices and specific types of work-related learning observed for a sample of the Dutch police force are likely to hold for other types of work contexts, but they need empirical grounding. Police participants score relatively high on task variation and task autonomy. This is typical for police work and culture, but it does not necessarily apply to other occupations. Finally, there is variance in work-related learning that remained unexplained and can thus be attributed to characteristics other than the ones considered here. Future research should therefore address other characteristics of workplace practices, such as job satisfaction (Rowden, 2002), personal interest in learning content, beliefs guiding work-related learning activities, and learning triggers.

\section{Directions for Further Research}

Spontaneous and deliberate learning are intertwined; workers develop competencies as a result of predefined learning goals and as a result of the work process itself. Berings, Doornbos, \& Simons (2006) therefore recommend using a number of data collection methods that offer different perspectives on work-related learning, such as observations affording insight into current activities and reflective interviews that encourage insight into stories of the past and people's intentions. These interviews ideally need to be conducted with people who were involved in the learning event and hold intersubjective perspectives on the same situation.

The question of how police officers give each other feedback and what makes social integration with colleagues and managerial support powerful in stimulating or inhibiting the possibilities for collegial feedback would be interesting study in more depth.

Police officers with long job tenure tend to have their own values and ways of learning. Future research may be directed at investigating work-related learning in relation to various stages of their professional work life and address the impact of learning experiences, as opposed to the frequency of their learning experiences. These 
are relevant questions in the continuing development of work-related learning and design of inviting workplace practices.

\section{References}

Argyris, C., \& Schön, D. (1996). Organizational learning II: Theory, method and practice. Reading, MA: Addison-Wesley.

Berings, M.G.M.C., Doornbos, A. J., \& Simons, P. R. J. (2006). Methodological practices in on-the-job learning research. Human Resource Development International, 9(3), 333363.

Billett, S. (2002). Workplace pedagogic practices: Co-participation and learning. British Journal of Educational Studies, 50(4), 457-481.

Courville, T., \& Thompson, B. (2001) Use of structure coefficients in published multiple regression articles: $B$ is not. Educational and Psychological Measurement, 61(2) 229248.

D'abate, C., Eddy, E. R., \& Tannenbaum, S. I. (2003). What's in a name? A literature based approach to understanding mentoring coaching, and other constructs that describe developmental interactions. Human Resource Development Review, 2(4), 360384.

De Laat, M. F., \& Simons, P. R. J. (2002). Collective learning: Theoretical perspectives and ways to support networked learning. European Journal for Vocational Training, 27(3), 14-27.

Doornbos, A. J., Bolhuis, S., \& Denessen, E. (2004). The relation between work domains and work-related learning: The case of the Dutch police. International Journal of Training and Development, 8(3), 174-190.

Doornbos, A. J., Bolhuis, S., \& Simons, P.R.J. (2004). Modelling work-related learning on the basis of intentionality and developmental relatedness: A non-educational perspective. Human Resource Development Review, 3(3), 250-274.

Doornbos, A. J., van Eekelen, I., \& Koopmans, H. (2006). Learning in interactive work situations: It takes two to tango; why not invite both partners to dance? Human Resource Development Quarterly, 17, 135-138.

Eddy, E. R., D’Abate, C. P., Tannenbaum, S. I., Givens-Skeaton, S., \& Robinson, G. (2006). Key characteristics of effective and ineffective developmental interactions. Human Resource Development Quarterly, 17(1), 59-84. 
Ellinger, A. D. (2005). Contextual factors influencing informal learning in a workplace setting: The case of "Reinventing Itself Company." Human Resource Development Quarterly, 16(3), 389-415.

Ellström, P. E. (2001). Integrating learning and work: Problems and prospects. Human Resource Development Quarterly, 12(4), 421-435.

Engeström, Y. (1999). Innovative learning in work teams: Analyzing cycles of knowledge creation in practice. In Y. Engeström, R. Miettinen, \& R. L. Punamäki (Eds.),

Perspectives on activity theory (pp. 377-404). Cambridge: Cambridge University Press. Eraut, M. (2000). Non-formal learning and tacit knowledge in professional work. British Journal of Educational Psychology, 70, 113-136.

Eraut, M., Alderton, J., Cole, G., \& Senker, P. (1998). Development of knowledge and skills in employment. Brighton, UK: University of Sussex Institute of Education.

Fenwick, T. J. (2001). Tides of change: New themes and questions in workplace learning. New Directions for Adult and Continuing Education, no. 92. San Francisco: Jossey-Bass.. Sociocultural Perspectives on Learning through Work . Issue Edited by Tara Fenwick, p. 3-18.

Fuller, A., \& Unwin, L. (2004a). Expansive learning environments: Integrating organizational and personal development. In H. Rainbird, A. Fuller, \& A. Munro (Eds.), Workplace learning in context (pp. 126-144). London: Routledge.

Fuller, A., \& Unwin, L. (2004b). Young people as teachers and learners in the workplace: Challenging the novice-expert dichotomy. International Journal of Training and Development, 8(1), 32-42.

Higgins, M. C., \& Kram, K. E. (2001). Reconceptualizing mentoring at work: A developmental network perspective. Academy of Management Review, 26(2), 264-288. Hodkinson, P., \& Hodkinson, H. (2004). The complexities of workplace learning. Problems and dangers in trying to measure attainment. In H. Rainbird, A. Fuller, \& A. Munro (Eds.), Workplace learning in context (pp. 259-275). London: Routledge. Kerngegevens Nederlandse Politie 2004 [Core information Dutch Police 2004]. (2005). Den Haag: Ministerie van Binnenlandse Zaken en Koninkrijksrelaties [Department of the Interior Home Office and Kingdom Relations].

Kram, K. E. (1985). Mentoring at work. Developmental relationships in organizational life. Glenview, IL: Scott Foresman.

Kwakman, C.H.E. (1999). Leren van docenten tijdens de beroepsloopbaan. Studies naar professionaliteit op de werkplek in het voortgezet onderwijs [Teacher learning: Studies in 
professionalism in the workplace in secondary education]. Nijmegen, Netherlands: University of Nijmegen.

Levy, D. A., Collins, B. E., \& Nail, P. R. (1999). A new model of interpersonal influence characteristics. Journal of Social Behavior and Personality, 13(4), 715-733.

Lohman, M. C. (2005). A survey of factors influencing the engagement of two professional groups in informal workplace learning activities. Human Resource Development Quarterly, 16(4), 501-527.

Marsick, V. J., \& Watkins, K. E. (1990). Informal and incidental learning in the workplace. London: Routledge.

Marsick, V. J., \& Watkins K. E. (2003). Demonstrating the value of an organization's learning culture: The dimensions of the learning organization questionnaire. Advances in Developing Human Resources 5(2), 132-151.

Marsick, V., \& Volpe, F. (1999). The nature and need for informal learning. Advances in Developing Human Resources, 3, 1-9.

McCauley, C. D., \& Hezlett, S. A. (2001). Individual development in the workplace. In N. Anderson (Ed.), Handbook of industrial, work and organizational psychology (pp. 313335). London: Sage.

McCauley, C. D., Ruderman, M. N., Ohlott, P. J., \& Morrow, J. E. (1994). Assessing the developmental components of managerial jobs. Journal of Applied Psychology, 79(4), 544560.

McLean G. N., Yang, B., Kuo, M. H., Tolbert, A., \& Larkin, C. (2005). Development and initial validation of an instrument measuring managerial coaching behavior. Human Resource Development Quarterly, 16(2) 157-178.

Palonen, T., Hakkarainen, K., Talvitie, J., \& Lehtinen, E. (2003). Network ties, cognitive centrality, and team interaction within a telecommunication company. In P. A.

Boshuizen, H. Gruber, \& R. Bromme (Eds.), Professional development: Gaps and transitions on the way from novice to expert (pp 271-294). Utrecht, Netherlands: Kluwer. Rainbird, H., Fuller, A., \& Munro, A (2004). Workplace learning in context. London: Routledge.

Rowden, R. W. (2002). The relationship between workplace learning and job satisfaction in U.S. small to midsize businesses. Human Resource Development Quarterly, 13(1), $407-425$. 
Ryan, R. M., \& Deci, E. L. (2000). Self-determination theory and the facilitation of intrinsic motivation, social development, and well-being. American Psychologist, 55(1), 68-78.

Salomon, G., \& Perkins, D. N. (1998). Individual and social aspects of learning. Review of Research in Education, 23, 1-24.

Stadler, M. A., \& Roediger, H. L., III. (1998). The question of awareness in research on implicit learning. In M. A. Stadler (Ed.), Handbook of implicit learning. Thousand Oaks, CA: Sage.

Straka, G. A. (1999). Perceived work conditions and self-directed learning in the process of work. International Journal of Training and Development, 3(4), 240-249.

Thijssen, J.G.L. (2006). De tweede loopbaanhelft [the second part of job tenure]. Utrecht: USBO.

Van der Krogt, F. J. (1998). Learning network theory: The tension between learning systems in organizations. Human Resource Development Quarterly, 9(2), 157-177. Van Veldhoven, M.J.P.M., \& Meijman, T. (1994). Het meten van psychosociale arbeidsbelasting met een vragenlijst. De vragenlijst Beleving en Beoordeling van de Arbeid (VBBA) [Measuring psychosocial work demands and job stress with a questionnaire: Perception and assessment of work]. Amsterdam: Nederlands Instituut voor Arbeidsomstandigheden [Dutch Institute for Working Conditions]. Van Woerkom, M. (2003). Critical reflection at work: Bridging individual and organisational learning. Enschede, Netherlands: Twente University.

Anja J. Doornbos is consultant at Kessels \& Smit, the Learning Company. She received her Ph.D. in 2006 on Work-Related Learning at the Dutch Police Force. Her research interests include informal learning behavior and developmental relatedness.

Robert-Jan Simons is a professor at the Institute of Education (IVLOS) of Utrecht University focusing on ICT and learning, especially in higher education.

Eddie Denessen is an assistant professor in the Department of Educational Sciences at Radboud University Nijmegen, the Netherlands. His research interests include parent involvement, school choice, culture differences in education, and teacher behaviour. 
Appendix A: Questionnaire Items and Factor Loadings (Pattern Coefficients) for Work-

Related Learning $(n=427)$

\begin{tabular}{|c|c|c|c|c|c|c|}
\hline \multirow[t]{2}{*}{ Scale and Item } & \multicolumn{5}{|c|}{ Factor } & \multirow[b]{2}{*}{6} \\
\hline & 1 & 2 & 3 & 4 & 5 & \\
\hline \multicolumn{7}{|l|}{ Learning from peer colleagues } \\
\hline Q48: reflecting on an event that suddenly gave new ideas (spontaneous) & .57 & .15 & -.04 & -.09 & -.18 & -.02 \\
\hline $\begin{array}{l}\text { Q39: purposefully observing a colleague to follow his or her example } \\
\text { (deliberate) }\end{array}$ & .54 & .00 & -.01 & -.13 & -.07 & .24 \\
\hline $\begin{array}{l}\text { Q45: asking questions to colleagues to get to the bottom of an issue } \\
\text { (deliberate) }\end{array}$ & .49 & -.10 & -.12 & .00 & -.11 & .24 \\
\hline $\begin{array}{l}\text { Q40: reflecting on what happened and contributing to each other's } \\
\text { understanding (deliberate) }\end{array}$ & .47 & -.04 & -.07 & -.27 & -.07 & .10 \\
\hline Q43: searching for information on a topic (deliberate) & .44 & .21 & -.16 & .07 & -.01 & .06 \\
\hline \multicolumn{7}{|l|}{ Learning individually } \\
\hline $\begin{array}{l}\text { Q11: preparing for a task and finding answers to different problems than } \\
\text { I was dealing with (spontaneous) }\end{array}$ & -.01 & .68 & -.08 & -.14 & .06 & .17 \\
\hline Q12: exploring a new application independently (deliberate) & .12 & .57 & -.06 & -.05 & -.15 & .06 \\
\hline $\begin{array}{l}\text { Q09: scrutinizing my personal performance and reflecting on what I } \\
\text { think about it (deliberate) }\end{array}$ & .22 & .33 & -.05 & -.07 & -.29 & -.11 \\
\hline \multicolumn{7}{|l|}{ Learning from outsiders } \\
\hline $\begin{array}{l}\text { Q18: deliberately searching for reactions of people outside the police } \\
\text { practice as a source for reflection (deliberate) }\end{array}$ & .02 & .02 & -.77 & -.06 & -.08 & -.10 \\
\hline $\begin{array}{l}\text { Q44: asking local residents for suggestions that help me in my work } \\
\text { (deliberate) }\end{array}$ & .09 & -.07 & -.61 & -.15 & .02 & .00 \\
\hline $\begin{array}{l}\text { Q17: chatting with citizens and they came with interesting ideas } \\
\text { (spontaneous) }\end{array}$ & .12 & .04 & -.52 & -.07 & .03 & .14 \\
\hline $\begin{array}{l}\text { Q10: deliberately choosing to perform a task that involved people } \\
\text { outside the police organization to expand boundaries (deliberate) }\end{array}$ & -.18 & .24 & -.51 & .13 & -.13 & .05 \\
\hline $\begin{array}{l}\text { Q41: observing an external police partner that turned out to be } \\
\text { unexpectedly informative (spontaneous) }\end{array}$ & .18 & .04 & -.43 & -.24 & -.04 & .10 \\
\hline \multicolumn{7}{|l|}{ Learning from new and less experienced colleagues } \\
\hline $\begin{array}{l}\text { Q28: watching a new colleague who just graduated, I noticed that I } \\
\text { could perform a task in a similar way (spontaneous) }\end{array}$ & -.09 & .05 & -.01 & -.82 & -.05 & .05 \\
\hline $\begin{array}{l}\text { Q26: talking to a less-experienced colleague to generate new ideas } \\
\text { (deliberate) }\end{array}$ & .10 & .07 & -.13 & -.68 & .03 & -.06 \\
\hline $\begin{array}{l}\text { Q29: reflecting on the work outcomes with the people involved in the } \\
\text { research, we came up with new ideas unexpectedly (spontaneous) }\end{array}$ & -.01 & .13 & -.09 & -.47 & -.26 & .04 \\
\hline $\begin{array}{l}\text { Q38: generating new ideas by monitoring colleagues who are less } \\
\text { knowledgeable than I am (deliberate) }\end{array}$ & .23 & -.07 & -.11 & -.46 & -.04 & .05 \\
\hline $\begin{array}{l}\text { Q27: informal conversing with a colleague resulted in learning some } \\
\text { interesting things unexpectedly (spontaneous) }\end{array}$ & .24 & .09 & .01 & -.43 & -.10 & .06 \\
\hline $\begin{array}{l}\text { Q08: starting to think differently about a subject from the contribution } \\
\text { of a colleague who had just started working at the police (spontaneous)[ }\end{array}$ & -.20 & .05 & .14 & -.43 & -.17 & .16 \\
\hline \multicolumn{7}{|l|}{ Learning together } \\
\hline $\begin{array}{l}\text { Q15: brainstorming about how to approach a shared problem, we } \\
\text { learned from each other spontaneously (spontaneous) }\end{array}$ & .11 & -.02 & -.08 & .05 & -.81 & -.04 \\
\hline $\begin{array}{l}\text { Q14: in meetings with colleagues with whom I work on a project, we } \\
\text { reached a united understanding unexpectedly (spontaneous) }\end{array}$ & -.04 & .00 & .04 & -.01 & -.76 & .12 \\
\hline $\begin{array}{l}\text { Q05: discussion with my colleague resulted in a joint statement } \\
\text { (deliberate) }\end{array}$ & -.03 & .03 & -.02 & -.11 & -.46 & .04 \\
\hline $\begin{array}{l}\text { Learning from expert colleagues } \\
\text { Q03: using the knowledge of more experienced colleagues }\end{array}$ & .09 & .03 & -.08 & .05 & -.04 & .66 \\
\hline
\end{tabular}
(deliberate) 
Q02: asking a more experienced colleague something and incidentally coming across something else helping me forward (spontaneous)

Q20: lacking certain skills and asking a colleague to help me develop them (deliberate)

$\begin{array}{llllll}.01 & .20 & .13 & -.10 & -.11 & .56 \\ .13 & -.13 & -.09 & -.17 & -.21 & .32\end{array}$

Appendix B: Questionnaire Items and Factor Loadings (Pattern Coefficients) for

Workplace Characteristics $(n=408)$

\begin{tabular}{|c|c|c|c|c|c|c|c|c|c|}
\hline \multirow[t]{2}{*}{ Scale and Item } & \multicolumn{9}{|c|}{ Factor } \\
\hline & 1 & 2 & 3 & 4 & 5 & 6 & 7 & 8 & 9 \\
\hline \multicolumn{10}{|l|}{ Personal characteristics } \\
\hline \multicolumn{10}{|l|}{ Experience of competence } \\
\hline Q18: I feel secure about the way I perform my tasks & .09 & .73 & -.02 & -.04 & -.02 & .03 & .02 & -.08 & -.01 \\
\hline $\begin{array}{l}\text { Q06: I am competent enough to perform my work } \\
\text { well }\end{array}$ & -.07 & .71 & .02 & .08 & .04 & -.09 & -.08 & .00 & -.11 \\
\hline Q22: I am confident about my own abilities & .02 & .63 & -.02 & .05 & -.01 & .11 & -.01 & -.07 & -.15 \\
\hline Q07: I feel that I can do my work effectively & -.01 & .61 & -.04 & -.04 & -.07 & .10 & .04 & .06 & .04 \\
\hline $\begin{array}{l}\text { Q14: I am not inferior to my co-workers in terms of } \\
\text { competence }\end{array}$ & -.01 & .58 & .00 & .05 & .09 & -.21 & -.05 & -.10 & -.27 \\
\hline Q03: I am satisfied with the quality of my work & -.06 & .54 & .03 & -.10 & .01 & .09 & -.06 & .05 & .07 \\
\hline \multicolumn{10}{|l|}{ Value of learning at work } \\
\hline $\begin{array}{l}\text { Q13: I want to apply new developments in my work } \\
\text { practice }\end{array}$ & .00 & .07 & .01 & -.04 & .02 & -.01 & -.02 & -.06 & -.54 \\
\hline $\begin{array}{l}\text { Q01: I want to develop by being open to people } \\
\text { outside the police }\end{array}$ & -.04 & -.01 & .00 & .00 & .07 & -.11 & -.03 & .05 & -.51 \\
\hline $\begin{array}{l}\text { Q05: I want to share my ideas on good police work } \\
\text { with co-workers }\end{array}$ & .00 & .01 & .00 & -.01 & .03 & .17 & -.02 & .05 & -.44 \\
\hline $\begin{array}{l}\text { Q17: I want to share my experiences with new } \\
\text { colleagues }\end{array}$ & -.01 & .07 & -.05 & -.02 & .01 & .13 & .06 & .08 & -.43 \\
\hline Q21: I consider my own development & .08 & .10 & -.02 & .03 & -.07 & .07 & .02 & -.03 & -.33 \\
\hline \multicolumn{10}{|l|}{ Relational characteristics } \\
\hline \multicolumn{10}{|l|}{ Social integration with colleagues } \\
\hline Q23: I have faith in the people I work with & .04 & .13 & -.05 & .02 & .00 & .76 & .07 & .02 & .06 \\
\hline Q04: I am proud of the people I work with & -.02 & .01 & .05 & -.10 & .03 & .68 & -.10 & .08 & -.07 \\
\hline Q11: I feel connected to my co-workers & -.01 & -.01 & .03 & -.05 & .03 & .51 & -.04 & .04 & -.13 \\
\hline \multicolumn{10}{|l|}{ Managerial support } \\
\hline $\begin{array}{l}\text { Q17: My manager cares about continuing } \\
\text { development }\end{array}$ & .80 & .01 & .02 & .02 & -.03 & .02 & .04 & .01 & -.01 \\
\hline $\begin{array}{l}\text { Q18: My manager gives me feedback on my } \\
\text { performance }\end{array}$ & .77 & .04 & .01 & .02 & .01 & -.02 & .03 & .14 & .06 \\
\hline Q26: My manager encourages me to take initiative & .74 & -.02 & .00 & -.07 & .01 & -.06 & -.04 & .02 & -.10 \\
\hline Q39: My manager encourages me to learn & .74 & -.05 & .07 & -.05 & .04 & .07 & -.15 & -.06 & .07 \\
\hline Q19: My manager gives me attention & .70 & -.09 & -.14 & -.05 & .01 & .12 & .14 & .01 & -.06 \\
\hline Q25: My manager discusses career steps with me & .69 & .01 & .02 & .09 & -.07 & -.09 & .00 & .00 & -.06 \\
\hline $\begin{array}{l}\text { Q32: My manager gives me insight into the } \\
\text { judgment of my work }\end{array}$ & .68 & .09 & .06 & .01 & .03 & .01 & -.04 & .09 & .13 \\
\hline Q11: My manager invites me to share ideas & .63 & -.04 & -.07 & -.06 & .07 & .01 & -.09 & -.02 & -.01 \\
\hline \multicolumn{10}{|l|}{ Possibilities for collegial feedback } \\
\hline $\begin{array}{l}\text { Q15: My colleagues tell me what they think of my } \\
\text { work }\end{array}$ & .08 & -.04 & .00 & .00 & .08 & .09 & -.05 & .69 & -.05 \\
\hline $\begin{array}{l}\text { Q23: I receive constructive criticism from my } \\
\text { colleagues }\end{array}$ & .21 & -.09 & .09 & -.03 & -.14 & .07 & -.09 & .60 & -.10 \\
\hline $\begin{array}{l}\text { Possibilities for participating in a network } \\
\text { Q38: In my work I am free to build and expand a } \\
\text { network }\end{array}$ & .00 & .04 & -.12 & .00 & -.01 & .07 & -.85 & -.02 & -.01 \\
\hline
\end{tabular}


Q24: I have the possibility to participate in a

$\begin{array}{lllllllll}.07 & .07 & -.06 & -.04 & -.01 & -.02 & -.66 & .11 & .06\end{array}$

(social) network

Work characteristics

Task variation

Q21: The tasks I have to perform are fascinating

$\begin{array}{lllllllll}.06 & -.06 & .06 & -.82 & -.03 & .12 & -.04 & -.12 & -.03\end{array}$

Q13: I have variation in my work

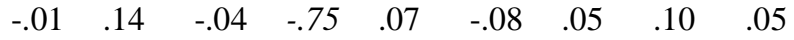

Q28: My work is challenging

$\begin{array}{llllllllll}.01 & -.10 & .01 & -.75 & -.08 & .10 & -.07 & -.05 & -.04\end{array}$

Q06: There is alternation in my work

$\begin{array}{lllllllll}.01 & .06 & -.08 & -.73 & .03 & -.06 & .00 & .10 & .02\end{array}$

Task autonomy

Q33: I decide how much time I spend on an activity $\quad \begin{array}{lllllllll}-.03 & -.06 & -.82 & .02 & .00 & -.06 & .02 & .03 & -.09\end{array}$

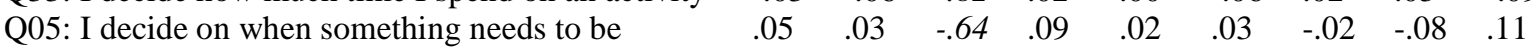

finished

Q46: I plan my own work

$\begin{array}{lllllllll}.02 & .01 & -.61 & .00 & -.06 & .01 & -.16 & -.03 & -.10\end{array}$

Q12: I decide what the content of my work will be

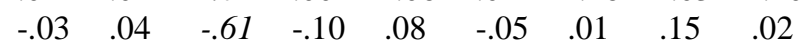

Q34: I can interrupt my work whenever I need to

$\begin{array}{lllllllll}-.04 & -.03 & -.60 & .02 & -.05 & .01 & -.05 & -.01 & -.02\end{array}$

Q20: I have autonomy in doing my work

$\begin{array}{lllllllll}.05 & .05 & -.56 & -.23 & .01 & .03 & -.01 & -.10 & .01\end{array}$

Work pressure

Q36: I have to work fast to get the job done

$\begin{array}{lllllllll}.00 & -.11 & -.05 & -.08 & .75 & -.05 & -.07 & -.03 & -.12\end{array}$

Q48: I have to work hard because of a personnel

$\begin{array}{lllllllll}.00 & .07 & .12 & .01 & .62 & .01 & .03 & .03 & .07\end{array}$

shortage

Q07: I am very busy on account of routine jobs that $\quad \begin{array}{llllllllll}01 & .10 & -.14 & -.03 & .53 & .02 & .07 & .07 & .03\end{array}$

need to be done

Q22: I can take my time with my work (recoded) $\quad$\begin{tabular}{lllllllllll} 
& .04 & -.15 & .07 & .13 & .50 & .07 & -.07 & -.14 & -.12 \\
\hline
\end{tabular} 